\title{
PRODUKTIVITAS JAMU PADA MASYARAKAT ARGOMULYO DI MASA PANDEMI
}

\author{
Nenden Susilowati \\ Universitas Negeri Yogyakarta, Indonesia \\ nendensusilowati87@uny.ac.id
}

\begin{abstract}
Abstrak: Penelitian ini bertujuan untuk mengetahui pengaruh motivasi, disiplin dan pengalaman terhadap produktivitas jamu pada masyarakat Argomulyo di tengah pandemi. Penelitian ini berjenis eksplanatif. Populasi dari penelitian adalah masyarakat di Kelurahan Argomulyo. Sampel sejumlah 35 pedagang jamu tradisional dengan pengambilan sampel melalui teknik purposive sampling. Data yang digunakan adalah data primer dihasilkan dari penelitian lapangan. Data dikumpulkan lewat angket dan proses pengamatan. Analisis data menggunakan analisis regresi berganda. Hasil penelitian adalah sebagai berikut. Pertama, motivasi memberikan pengaruh yang signifikan terhadap produktivitas. Kedua, displin memberikan pengaruh yang signifikan terhadap produktivitas. Ketiga, pengalaman memberikan pengaruh signifikan terhadap produktivitas.
\end{abstract}

Kata kunci: Motivasi, Disiplin, Pengalaman , Produktivitas

\section{JAMU PRODUCTIVITY IN ARGOMULYO SOCIETY IN THE PANDEMIC PERIOD}

\begin{abstract}
This study aims to determine the effect of motivation, the discipline and experience on the productivity of herbal medicine in the Argomulyo community during a pandemic. This research is of an explanative type. The population of this research is the people in Argomulyo Village. The sample was 35 traditional herbal medicine traders with a purposive sampling technique. The data used are primary data generated from field research. Data were collected through questionnaires and observation processes. Data analysis using multiple regression analysis. The results of the study are as follows. First, motivation has a significant effect on productivity. Second, the discipline has a significant effect on productivity. The three, experiences have a significant influence on productivity.
\end{abstract}

Kata kunci: Motivation, The Discipline, Experience, Productivity

\section{PENDAHULUAN}

Sejak dimulainya wabah Covid-19 di Wuhan Tiongkok pada bulan November 2019 penyebaran virus korona secara global semakin menggelisahkan. Perkembangan kasus COVID-19 di Wuhan berawal pada tanggal 30 Desember 2019 dimana Wuhan Municipal Health Committee mengeluarkan pernyataan "urgent notice on the treatment of pneumonia of unknown cause". Penyebaran virus Corona ini sangat cepat bahkan sampai ke lintas negara. Penyebaran virus Corona yang telah meluas ke berbagai belahan dunia dan salah satunya membawa dampak yang serius pada perekonomian Indonesia. Hal ini sesuai dengan pendapat Hanoatubun (Hanoatubun, 2020) yang mengemukakan bahwa sektor ekonomi yang terdampak paling parah akibat covid 19 dalam perekonomian Indonesia adalah perdagangan. Penerimaan pajak dari sektor perdagangan menempati posisi kedua terbesar di Indonesia, sehingga hal tersebut menimbulkan economic shock baik bagi individu, usaha mikro, menengah dan besar yang jangkuannya tidak hanya dirasakan masyarakat lokal tetapi juga secara global. 
Menurut Warjiyo (Warjiyo \& Juhro, 2016), masalah ekonomi global yang berdampak serius terhadap ekonomi Indonesia sudah diprediksi sejak kasus pertama COVID-19 yang dilaporkan oleh pemerintah pada tanggal 2 Maret 2020 yaitu berjumlah dua orang, selang tiga minggu meningkat menjadi 369 orang. Kejadian tersebut menimbulkan masalah panic buying yang diikuti dengan lesunya kegiatan industri, sehingga berimbas pada perlambatan pertumbuhan ekonomi. Pertumbuhan ekonomi masih dianggap sebagai sesuatu yang mutlak dan diperlukan dalam mengukur kemajuan perekonomian suatu negara. Pada umumnya pertumbuhan ekonomi tersebut dijadikan sebagai tolak ukur dalam melakukan evaluasi atas kebijakan yang telah dilaksanakan selama ini. Hal itu sesuai dengan pendapat Sukirno (Sukirno, 2011) suatu negara mampu meraih pencapaian tertinggi apabila kegiatan ekonominya meningkat daripada periode sebelumnya serta diimbangi dengan perputaran barang atau jasa yang berlangsung secara cepat dan bertambah secara berkala.

Berdasarkan data dari Kementerian Koperasi (Herman, 2020) yang menggambarkan bahwa sejumlah 185.184 pelaku Usaha Mikro Kecil dan Menengah (UMKM) terdampak pandemi COVID-19. Kebanyakan sektor UMKM yang paling terdampak yaitu bidang kuliner. Dalam mengatasi masalah yang dihadapi pelaku UMKM, pemerintah menawarkan beberapa solusi. Salah satunya adalah memasukkan pelaku UMKM sebagai penerima program bantuan seperti Kartu Prakerja. Walapun dalam pelaksanaan program tersebut masih mengalami prokontra ditengah masyarakat, harapannya Kartu Prakerja bisa memberikan angin segar bagi pelaku UMKM untuk mengembalikan usaha mereka agar lebih stabil. Meskipun pandemi COVID-19 memunculkan berbagai masalah bagi pelaku UMKM, di sisi lain muncul adanya peluang untuk bisa menaikkan omset penjualan produk khususnya pada produk kesehatan dan makanan herbal. Hal ini sejalan dengan pendapat Panigoro (Ridwan, 2020) yang menjelaskan bahwa peningkatan konsumsi produk kesehatan herbal seperti jamu di kalangan masyarakat dikarenakan sudah menjadi kebutuhan ditengah adaptasi kebiasaan hidup baru.

Makanan herbal atau jamu tradisional telah menjadi bagian dari kebiasaan hidup dari masyarakat yang tinggal di Indonesia, bahkan sudah tersebar di seluruh pelosok tanah air. Berdasarkan hasil Riset Kementrian Kesehatan(Peraturan Menteri Kesehatan Republik Indonesia Nomor 006 Tahun 2012 Tentang Industri Dan Usaha Obat Tradisional, 2012) menunjukkan bahwa sebanyak 49,53 persen penduduk Indonesia yang berusia 45 tahun ke atas mengonsumsi jamu. Selama Covid-19 intensitas masyarakat dalam mengkonsumsi jamu sebagai penguatan daya tahan tubuh bertambah sebesar 5\% penduduk setiap hari. Jenis obat tradisional yang paling banyak dikonsumsi adalah berbentuk cair $(55,16$ persen) sisanya dalam bentuk tablet. Jamu merupakan bagian dari pengobatan tradisional yang telah berkembang secara luas di banyak negara dan semakin populer. Tidak jarang beberapa kalangan masyarakat lebih memilih menggunakan pengobatan tradisional dibandingkan dengan medis. Hal ini terjadi dikarenakan biaya yang dianggap relatif lebih murah. 
Menurut Masduki (Hardum, 2020) menjelaskan bahwa dengan adanya covid-19 pelaku UMKM khususnya yang bergerak di sektor ramuan tradisional atau jamu justru diuntungkan. Dengan keberadaan covid-19 yang semakin mengkhawatirkan di Indonesia sejak beberapa waktu lalu, permintaan terhadap komoditas pangan untuk jamu terus meningkat. Usaha jamu tradisional skala kecil dan mikro dikembangkan menjadi usaha jamu racikan. Berdasarkan Peraturan Menteri Kesehatan RI No. 006 Th. 2012, pasal 2 ayat 3 terfokus pada jamu tradisional yaitu jamu gendong, usaha ini teridentifikasi masih terdapat perdebatan panjang terkait pengelolaan kualitas dari jamu tradisional. Namun tidak bisa dipungkiri jamu tradisional sebagai salah satu bagian mata rantai usaha herbal memiliki andil besar dikembangkan sebagai basis ketahanan ekonomi kerakyatan khususnya meningkatkan peran dari womenprenur ditengah masa pandemi saat ini. Dari omset jamu tradisional di atas, angka sangat fantastik diraih oleh usaha jamu tradisional hingga mencapai Rp. 1,3 trilyun di tahun 2011. Dari uraian diatas, penulis tertarik untuk meneliti faktor pembentuk peningkatan produktivitas jamu di kalangan masyarakat di masa pandemi. Berdasarkan penelitian yang dilakukan oleh Muhwan (Muhwan \& Puryandani, 2019) menjelaskan bahwa ada tiga faktor pembentuk produktivitas yaitu disiplin, motivasi dan pengalaman. Disiplin menggambarkan wujud keajegan tenaga kerja dalam menjaga kualitas, motivasi sebagai motor penggerak untuk terus berkreasi dan pengalaman sebagai pembentuk kepakaran dari masing- masing tenaga kerja yang dibangun seiring dengan rentang waktu mereka bekerja. Hal yang membedakan dalam penelitian ini adalah ketiga faktor pembentuk produktivitas tersebut diukur bukan dari sudut pandang tenaga kerja tetapi pedagang usaha mikro mengingat produsen jamu tradisional di Desa Argomulyo mayoritas tidak memiliki tenaga kerja. Selain itu penelitian ini dilakukan ditengah kondisi ekonomi yang terpuruk, sehingga dilihat dari kondisi dan subyek penelitian yang berbeda peneliti ingin melihat seberapa besar pengaruh dari motivasi, displin dan pengalaman terhadap produktivitas produsen jamu pada masyarakat Argomulyo di masa pandemic.

\section{METODE}

Jenis penelitian yang telah dilakukan adalah penelitian eksplanatif dengan pendekatan kuantitatif. Penelitian ini dilakukan di Desa Argomulyo, Sedayu, Bantul. Populasi dalam penelitian adalah produsen jamu tradisional di Desa Argomulyo. Daerah yang terdampak covid19 terbanyak di wilayah Yogyakarta adalah Kabupaten Bantul. Hal tersebut menjadi peluang bagi para produsen jamu untuk meningkatkan omset penjualan, mengingat banyak produsen minuman herbal yang meraup keuntungan dengan adanya covid-19 ini. Desa Argomulyo merupakan daerah penghasil produsen jamu terbanyak di Kabupaten Bantul. Selain itu Desa Argomulyo merupakan salah satu daerah di Kabupaten Bantul yang dikenal memiliki sentra jamu tradisional yaitu dengan didirikannya Omah Jamu. Omah Jamu berdiri atas kerjasama antara pemerintah desa, PT. Pertamina dan masyarakat. Selain itu terdapat kelompok tani Jati Usaha Mulya sebagai 
paguyuban produsen jamu yang berperan menjadikan jamu tradisional menjadi salah satu produk unggulan daerah di Kabupaten Bantul. Dalam pengambilan sampling menggunakan metode Purposive Sampling dikarenakan tidak semua dusun di Desa Argomulyo memiliki penduduk yang bermata pencaharian sebagai produsen jamu tradisional. Hal ini sesuai dengan pendapat Sugiyono (Sugiyono, 2016) bahwa purposive sampling adalah teknik pengambilan sampel memperhitungkan alasan dan estimasi tertentu. Sampel dalam penelitian ini berjumlah 35 produsen jamu tradisional. Hal ini merujuk dari pendapat Sugiyono (Sugiyono, 2011) bahwa ambang batas pengukuran sampel dikatakan aksebtabel berkisar antara 30 sampai 500 sampel.

Proses pengumpulan data dilakukan dengan dua cara yaitu melalui observasi dan angket. Angket yang diberikan kepada responden mengukur terkait tingkat produktivitas jamu pada masyarakat di Desa Argomulyo dengan skala likert yaitu menggunakan 5 pilihan. Dalam angket tersebut mengukur seberapa besar kontribusi ketiga faktor pembentuk terhadap tingkat produktivitas dari produsen jamu tradisional. Ada tiga variabel yang dicantumkan dalam angket tersebut yaitu motivasi, disiplin dan pengalaman. Tahap analisis data yang dilakukan penulis menggunakan dua tahapan yaitu pertama, uji prasyarat sebelum melakukan analisis regresi berganda. Uji tersebut meliputi uji normalitas, uji linearitas, uji multikolinearitas, dan uji heteroskedastisitas. Kedua, data tersebut kemudian dianalisis menggunakan teknik analisis regresi berganda. Analisis regresi berganda digunakan untuk melihat pengaruh langsung dari variabel motivasi, disiplin dan pengalaman terhadap tingkat produktivitas. Struktur persamaan yang akan terbentuk setelah proses analisis data sebagai berikut:

$\mathrm{Y} 1=\mathrm{pY} X_{1}+\mathrm{pY} X_{2}+\mathrm{pY} X_{3}+\mathrm{e} 1$

Keterangan :

Y : produktivitas

$p Y X_{1} \quad$ : besarnya pengaruh variabel motivasi terhadap produktivitas

pYX $X_{2} \quad$ : besarnya pengaruh variabel disiplin terhadap produktivitas

$p Y X_{3} \quad$ : besarnya pengaruh variabel pengalaman kerja terhadap produktivitas

e1

: Standar eror

\section{HASIL DAN PEMBAHASAN}

Analisis dilakukan kepada 35 responden dengan hasil pengujian prasyarat mengungkapkan bahwa data berdistribusi normal dan linier, serta terbebas dari multikolinearitas dan heteroskedastisitas. Berlandaskan uji prasyarat tersebut, maka dapat disimpulkan bahwa data sudah memenuhi syarat untuk dilakukan tahap selanjutnya yaitu analisis deskriptif dan analisis regresi berganda. Sebelum mencermati hasil analisis data, dibawah ini terdapat gambaran tentang persebaran demografi responden di Desa Argomulyo. 
Tabel 1. Demografi Responden

\begin{tabular}{lccc}
\hline \multicolumn{1}{c}{ Dusun } & Usaha Jamu & Responden & Persentase (\%) \\
\hline Sengon Karang & Seruni Putih & 8 & 22,86 \\
Watu & Jati Usaha Mulya & 18 & 51,43 \\
Sengon Madinan & Jati Usaha Mulya & 9 & 25,71 \\
Total & & 35 & $100 \%$
\end{tabular}

Dalam analisis deskriptif mengungkapkan bahwa setelah dilakukan penelitian dengan merujuk pada 35 responden mayoritas jumlah pendapatan produsen jamu tradisional di masa pandemi sebesar Rp 495.142 dibandingkan sebelum terjadinya covid -19 Rp 401.428, sehingga mengalami peningkatan sebesar 23\%. Apabila dilihat dari aspek produktivitas produk mayoritas produsen mengalami peningkatan sebesar $22 \%$ dibandingkan sebelum covid 19 . Hal ini sejalan dengan upaya pemerintah meningkatkan peran serta womenprenuer dalam meningkatkan ketahanan ekonomi kreatif. Selain itu kegiatan tersebut sebagai salah satu upaya untuk mendorong kesetaraan gender dalam program Suistainabel Development Goals. Hal ini juga relevan dengan penelitian yang dilakukan Andriati (Andriati \& Wahjudi, 2016) bahwa dari kalangan profesi tenaga kesehatan, perhatian terhadap obat tradisional mulai dirasakan, dengan berdirinya berbagai perhimpunan tenaga dokter yang intinya menggunakan tanaman obat/obat tradisional sebagai modalitas terapi dan media komplementer dalam pengobatan pasien. Pada akhirnya hal ini membantu mensejajarkan posisi jamu tradisional dengan pengobatan medis, sehingga keberadaan jamu tradisional akan semakin diperhitungkan dan memiliki daya saing yang kuat.

Namun dari total responden sebanyak 4 orang yang selama pandemi pendapatan dan produktivitas tidak mengalami peningkatan. Hal ini disebabkan karena produsen tersebut sudah berusia lanjut dan memiliki keterbatasan akses pemasaran seperti belum memiliki smartphone yang memungkinkan produsen untuk memasarkan secara online. Pada akhirnya mereka hanya bisa memasarkan dari rumah ke rumah hal ini tidak maksimal mengingat di era pandemi seperti ini banyak kawasan yang ditutup sehingga semakin menyulitkan produsen untuk memasarkan produknya. Berdasarkan penelitian Mulyadi (Aji et al., 2018) produktivitas seorang produsen dapat meningkatkan walaupun ditengah kondisi ekonomi suatu negara yang labil apabila didukung oleh keajegan dari produktivitas nilai yang tercermin dari sikap motivasi, disiplin, dan pengalaman. Berdasarkan pengujian statistik mengungkapkan seberapa besar pengaruh nilai motivasi, disiplin dan pengalaman terhadap produktivitas seorang produsen jamu tradisional, selengkapnya dapat dicermati melalui tabel 2 dibawah ini : 


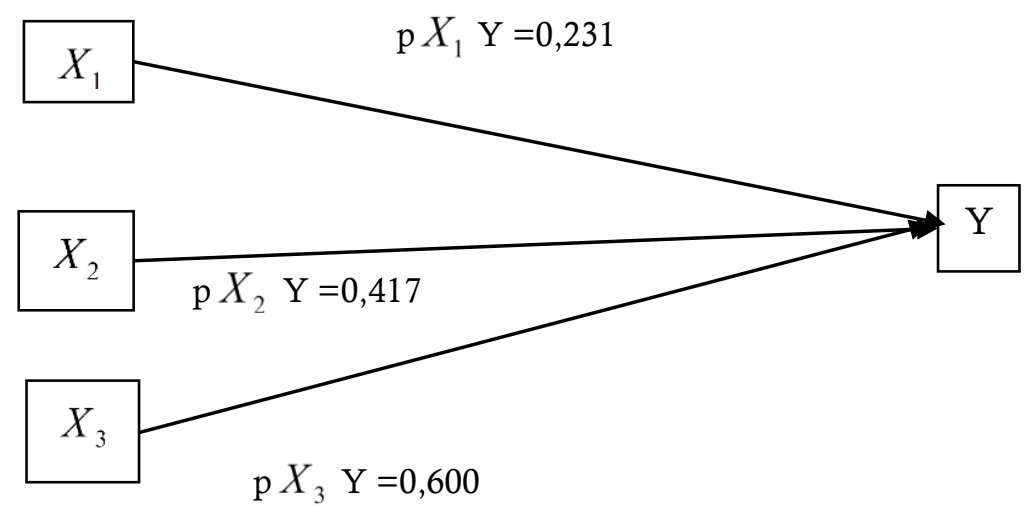

\section{Gambar 1. Paradigma Analisis Struktur}

Keterangan:

Y : produktivitas

$p Y X_{1} \quad$ : besarnya pengaruh variabel motivasi terhadap produktivitas

$p Y X_{2} \quad$ : besarnya pengaruh variabel disiplin terhadap produktivitas

$p Y X_{3} \quad$ : besarnya pengaruh variabel pengalaman kerja terhadap produktivitas

Berdasarkan hasil analisis regresi berganda yang terlihat dalam tabel 2 dan gambar paradigma mengungkapkan adanya tiga temuan terkait pengaruh langsung antara variabel motivasi, disiplin dan pengalaman secara parsial. Dalam pengujian statistik mengungkapkan bahwa nilai koefisien determinasi (R2) sebesar 0,715 atau sebesar 71,5\% seperti tabel diatas yang memiliki substansi bahwa $71,5 \%$ variabel tidak bebas atau produktivitas dapat diterangkan secara simultan oleh variabel bebas yaitu motivasi, disiplin dan pengalaman sedangkan sisanya $28,5 \%$ diterangkan dari faktor lainnya yang berasal dari luar model regresi linear ganda.

Temuan pertama, pengaruh secara parsial antara motivasi dengan produktivitas memiliki nilai siginifikasi sebanyak 0,021 $<0,05$ yang bermakna ada pengaruh antara motivasi dengan produktivitas. Motivasi berperan sebagai pembangkit semangat seorang produsen atau pengusaha untuk tetap melakukan proses produksi walapun di tengah pandemi seperti saat ini. Mereka harus tetap berpikir kreatif dan inovatif agar tetap bisa bertahan untuk memenuhi kebutuhan hidup mereka. Hal ini relevan dengan pendapat yang dikemukakan oleh Suwatno (Suwatno, 2003) bahwa orang mau tetap berkarya dan terus berkarya karena adanya motivasi untuk memenuhi kebutuhan, baik kebutuhan yang disadari maupun kebutuhan yang tidak disadari. Hal ini dikuatkan lagi oleh penelitian Purnama (Purnama, 2008) yang menjelaskan bahwa pelaksanaan motivasi kerja yang baik akan menghasilkan produktivitas yang tinggi, namun perlu diingat agar motivasi tersebut terus meningkat harus diimbangi dengan adanya hubungan yang baik dengan pihak mitra yang bersangkutan. Dengan demikian dapat disimpulkan bahwa motivasi merupakan 
modal dasar seorang produsen dalam menggali potensi yang dimilikinya untuk tetap berkarya, sehingga menjadi kekuatan untuk terus bangkit menjalankan aktivitas kewirausahannya. Selain itu ada hal penting yang perlu diperhatikan oleh seorang produsen yaitu menjaga hubungan antar anggota kelompok atau produsen lain sehingga bisa bersaing dengan sehat dan saling mendukung untuk menjadikan produk olahannya menjadi salah satu produk unggulan.

Temuan kedua hubungan parsial antara variabel disiplin dengan produktivitas yang memiliki nilai signifikansi sebesar 0,037 < 0,05 yang bermakna ada pengaruh antara disiplin dengan produktvitas. Disiplin mampu membangkitkan kinerja pada saat menjalankan suatu kegiatan atau usaha. Dengan memiliki sikap disiplin akan menunjukkan rasa antusias dan komitmen yang tinggi terhadap pekerjaannya, sehingga mampu meningkatkan produktivitas kerjanya. Hal ini relevan dengan pendapat yang dikemukakan oleh Lasnoto (Lasnoto, 2017) bahwa wujud disiplin yang tinggi akan tercemin pada meningkatnya semangat kerja sehingga memiliki alur kerja yang terstruktur dan pada akhirnya meningkatkan efisiensi. Penelitian ini juga relevan dengan pendapat dari Aspiyah (Aspiyah \& Martono, 2016) yang mengungkapkan bahwa disiplin berpengaruh signifikan terhadap produktivitas kerja pelaku usaha baik secara parsial maupun secara simultan. Hal ini dikuatkan oleh penelitian Ananta (Febri Ananta \& Dewi Adnyani, 2016) yang menjelaskan bahwa disiplin merupakan bagian yang dominan terhadap produktivitas kerja karena dalam jangka panjang akan mempengaruhi loyalitas karyawan agar lebih bertanggungjawab dalam menjalankan tugasnya. Dari pendapat diatas maka dapat disimpulkan bahwa sikap disiplin sangat dibutuhkan untuk menjaga efisiensi terhadap usahanya sehingga akan menghasilkan persaingan iklim usaha dengan sehat. Dengan demikian walaupun di tengah masa pandemi seperti ini para produsen jamu tradisional tetap konsisten dalam menjaga kualitas produknya, maka hasil yang diperolehpun akan meningkat.

Temuan ketiga, pengaruh secara parsial antara variabel pengalaman kerja dengan produktivitas memiliki nilai signifikansi sebanyak $0,049<0,05$ yang memiliki substansi adanya pengaruh antara pengalaman kerja dengan produktivitas. Pengalaman kerja sebagai bentuk sikap responsif dalam menghadapi perubahan atau kelesuan ekonomi seperti saat ini. Pengalaman juga digunakan untuk memperkirakan kompetensi seorang produsen terhadap pekerjaan dan sarana penunjang, sehingga memiliki gerakan yang lebih sigap dan fleksibel. Hal ini relevan dengan penelitian Muliani (Muliani \& Suresmiathi, 2015) yang mengemukakan bahwa pengalaman kerja berpengaruh positif dan signifikan terhadap produktivitas kerja. Dengan kata lain bahwa semakin banyak dan beragam pengalaman kerja yang dimiliki akan menyebabkan peningkatan jumlah produktivitas yang diperoleh. Hal ini sejalan dengan penelitian yang dilakukan oleh Lukman (Salju \& Lukman, 2019) bahwa pengalaman yang dimiliki seorang produsen akan menghasilkan sikap yang lebih cakap dan terampil serta mampu melaksanakan pekerjaannya menjadi lebih baik. Hal ini dikuatkan lagi oleh Sulaeman (Ardika Sulaeman, 2014) yang menjelaskan bahwa intensitas seorang pekerja dalam melakukan pekerjaan akan menjadikannya lebih terampil, dan 
keterampilan tersebut berdampak positif terhadap produktivitasnya. Dari uraian diatas dapat disimpulkan bahwa bagi seorang produsen jamu yang telah melalui proses panjang dalam menghadapi resiko, maka akan terbentuk pribadi yang lebih terampil dan memiliki produktivitas yang lebih baik.

\section{SIMPULAN}

Berdasarkan analisis deskripsi,pengolahan dan intepretasi data statistik, maka kesimpulan dari penelitian ini adalah adanya pengaruh antara motivasi, disiplin dan pengalaman terhadap produktivitas jamu pada masyarakat Argomulyo di Masa Pandemi. Dalam rangka meningkatkan produktivitas produsen jamu pada masyarakat Argomulyo ada tiga saran yang perlu disampaikan penulis. Pertama, menciptakan hubungan kerja yang lebih kondusif dengan mitra yang lain sehingga mampu meningkatkan motivasi untuk terus mengembangkan produknya. Kedua, produsen jamu agar lebih memperhatikan respon pelanggan terkait produk yang dipasarkan. Hal ini sangat penting untuk melihat sikap cepat tanggap yang dimiliki produsen seperti halnya konsumsi jamu tradisional selama covid- 19 meningkat, harapannya produsen mampu menciptakan kemasan jamu yang lebih praktis dan ramah lingkungan. Mengingat saat ini masih banyak dijumpai kemasan jamu dalam bentuk botol plastik. Produsen jamu mungkin bisa menciptakan kemasan dengan bahan yang lebih ramah lingkungan seperti corugated. Ketiga mengikuti pelatihan terkait teknologi pemasaran produk. Hal ini sangat penting mengingat dalam penelitian ini masih terdapat responden yang belum mampu mengoperasikan smartphone. Di era pandemi saat ini kegiatan transaksi akan lebih banyak melibatkan sistem pemasaran secara daring.

Keterbatasan dalam penelitian ini terkait jumlah responden, hal ini sebenarnya tidak sesuai dengan target peneliti. Mengingat proses pengumpulan data dilakukan di masa pandemi dan sesuai dengan arahan dari Pemerintah Desa Argomulyo adanya larangan aktivitas mengumpulkan warga dalam jumlah yang besar, maka peneliti hanya dapat mengambil jumlah sampel sebanyak 35. Walaupun demikian data dari setiap dusun penghasil jamu sudah terwakili. Hasil penelitian ini dapat digunakan sebagai masukan bagi Pemerintah Desa Argomulyo dalam membenahi dan mengembangkan produk jamu agar tetap bisa menjadi produk unggulan di masa pandemi dengan mengoptimalkan ketiga faktor pembentuk produktivitas para produsen jamu tradisional yaitu motivasi, disiplin dan pengalaman.

\section{DAFTAR PUSTAKA}

Aji, S. P., Mulyadi, H., \& Widjajanta, B. (2018). Keterampilan Wirausaha untuk Keberhasilan Usaha. Journal of Business Management Education, 3(3), 111-122. https://www.uam.es/gruposinv/meva/publicaciones jesus/capitulos_espanyol_jesus/2005_motivacion para el aprendizaje Perspectiva 
alumnos.pdf\%0Ahttps://www.researchgate.net/profile/Juan_Aparicio7/publication/25357 1379_Los_estudios_sobre_el_cambio_conceptual_

Andriati, A., \& Wahjudi, R. M. T. (2016). Tingkat penerimaan penggunaan jamu sebagai alternatif penggunaan obat modern pada masyarakat ekonomi rendah-menengah dan atas. Masyarakat, Kebudayaan Dan Politik, 29(3), 133-145. https://doi.org/10.20473/mkp.v29i32016.133-145

Ardika Sulaeman. (2014). Pengaruh Upah Dan Pengalaman Kerja terhadap Produktivitas Karyawan Kerajinan Ukiran Kabupaten Subang. Trikonomika, 13(1), 91-100.

Aspiyah, M., \& Martono, S. (2016). Pengaruh Disiplin Kerja, Lingkungan Kerja dan Pelatihan pada Produktivitas Kerja. Management Analysis Journal, 5(4), 339-346. https://doi.org/10.15294/maj.v5i4.12712

Febri Ananta, I., \& Dewi Adnyani, I. (2016). Pengaruh Disiplin Kerja Dan Budaya Orgasnisasi Terhadap Produktivitas Kerja Karyawan Pada Villa Mahapala Sanur-Denpasar. E-Jurnal Manajemen Ubud, 5(2), 1103-1130.

Hanoatubun, S. (2020). Dampak Covid-19 Terhadap Perekonomian Indonesia. Journal of Education, Psychology and Counseling, 2(1), 146-153.

Hardum, S. E. (2020). Teten Masduki: Pemerintah Main Peran UMKM Bangkitkan Ekonomi dalam Masa Pandemi Covid-19. Berita Satu. https://www.beritasatu.com/edihardum/ekonomi/644361/teten-masduki-pemerintah-main-peran-umkm-bangkitkanekonomi-dalam-masa-pandemi-covid19

Herman. (2020). 2.322 Koperasi dan 185.184 UMKM Terdampak Covid-19. Berita Satu. https://www.beritasatu.com/iman-rahman-cahyadi/ekonomi/642537/2322-koperasi-dan185184-umkm-terdampak-covid19

Lasnoto. (2017). Pengaruh Disiplin Kerja terhadap Produktivitas Kerja Karyawanperusahaan PT Luah Uwang Indonesia di Samarinda. Jurnal Ekonomi Dan Manajemen, 11(2), 260-269.

Peraturan Menteri Kesehatan Republik Indonesia Nomor 006 Tahun 2012 Tentang Industri dan Usaha Obat Tradisional, 1 (2012).

Muhwan, \& Puryandani. (2019). PENGARUH DISIPLIN, MOTIVASI DAN PENGALAMAN KERJA TERHADAP PRODUKTIVITAS KARYAWAN AREA LAYANAN MIKRO DI PT. BANK JATENG CABANG PEMALANG. Jurnal Magisma, VII(2), 63-70.

Muliani, N. M. S., \& Suresmiathi, A. . A. (2015). Pengaruh Pengalaman Kerja Terhadap Produktivitas Pengrajin untuk Menunjang Pendapatan Pengrajin. E-Jurnal Ekonomi Pembangunan Universitas Udayana, 5(5), 614-630. 
Purnama, R. (2008). Pengaruh Motivasi Kerja Terhadap Produktivitas Kerja Karyawan Pada Bagian Produksi Cv. Epsilon Bandung. Strategic : Jurnal Pendidikan Manajemen Bisnis, 8(2), 58. https://doi.org/10.17509/strategic.v8i2.1028

Ridwan. (2020). Selama Pandemi Covid-19, Konsumsi Jamu di Indonesia Meningkat. Juara News. https://juaranews.com/berita/40650/05/08/2020/selama-pandemi-covid-19-konsumsijamu-di-indonesia-meningkat

Salju, S., \& Lukman, M. (2019). Pengaruh Motivasi Dan Pengalaman Kerja Terhadap Produktivitas Kerja Karyawan Pt. Comindo Mitra Sulawesi Cabang Palopo. Jurnal Manajemen STIE Muhammadiyah Palopo, 4(2), 1-7. https://doi.org/10.35906/jm001.v4i2.280

Sugiyono. (2011). Metode Penelitian Kuantitatif, Kualitatif dan R\&D. ALFABETA.

Sugiyono. (2016). Metode Penelitian Kuantitatif Kualitataif dan Kombinasi (Mixed Methods). ALFABETA.

Sukirno, S. (2011). Teori Pengantar Makroekonomi. In Rajawali Press.

Suwatno. (2003). Azas-azas Manajemen Sumber Daya Manusia. Suci Press.

Warjiyo, P., \& Juhro, S. M. (2016). Kebijakan Bank Sentral Teori dan Praktik. Rajawali Pers. 